\title{
THE DEMISE OF "PARASITIC ACCESSORIAL LIABILITY”: SUBSTANTIVE JUDICIAL LAW REFORM, NOT COMMON LAW HOUSEKEEPING
}

\author{
FINDLAY STARK ${ }^{*}$
}

\begin{abstract}
In Jogee and Ruddock, the Supreme Court/Privy Council decided that the law on secondary liability took a "wrong turn" in 1984 in the Privy Council's decision in Chan Wing-Siu. Chan Wing-Siu's contemplation/foresight-based fault element for secondary liability was alleged by the Supreme Court/Privy Council to have bucked a legal trend towards requiring that the secondary party intended to encourage or assist every one of the principal's offences. This article presents an alternative history of secondary liability that explains a wider selection of cases from 1553-1984 than were considered in Jogee and Ruddock. On this alternative account, Chan Wing-Siu was simply a more explicit and intellectually honest decision than its predecessors. If this alternative view of history is accepted, the Supreme Court/Privy Council's claim to be merely "correcting" (rather than substantively reforming) the law of secondary liability should be rejected. Doing so would make clearer a question that was side-stepped in Jogee and Ruddock, i.e. whether this reform should have been undertaken by the judiciary, rather than the legislature.
\end{abstract}

KEYWORDS: Criminal law, accessories, parasitic accessorial liability, joint enterprise, judicial law reform

\section{INTRODUCTION}

"Parasitic accessorial liability"1 (PAL) allowed D1, a party sharing D2's purpose to commit Offence A (e.g. burglary), to be held liable as a secondary party for D2's further ("collateral") Offence B (e.g. murder). What (controversially) distinguished PAL from "ordinary" accessorial liability (i.e. aiding, abetting, counselling or procuring) was that D1 could be liable for Offence B without proof that she encouraged or assisted ${ }^{2}$ its commission, let alone that she did so intentionally. ${ }^{3}$ In its modern incarnation, PAL required only that D1 had

\footnotetext{
* University Lecturer in Criminal Law, University of Cambridge. Thanks to John Baker, Mark Dsouza, Matthew Dyson, P.R. Glazebrook, Chloë Kennedy, Henry Mares, Simon Mackay, Nick McBride, Jonathan Rogers, Rajiv Shah, Graham Virgo and two anonymous referees for reading and commenting on earlier drafts. Thanks also to Renaud Morieux for help in translating some sources. Address for correspondence: Dr. Findlay Stark, Jesus College, Cambridge CB5 8BL. E-mail: fgs23@cam.ac.uk.

${ }^{1}$ A label coined in J.C. Smith, "Criminal Liability of Accessories: Law and Law Reform" (1997) 113 L.Q.R. 453, 455 (hereafter Smith, "Accessories"). cf. G.J. Virgo, "Joint Enterprise is Dead: Long Live Accessorial Liability" [2012] Crim. L.R. 850, 855-856.

${ }^{2}$ Procurement was ignored in Jogee, but will be mentioned at various points below.

${ }^{3}$ Where no collateral Offence B occurred, the "common purpose" usually did no useful work: B. Krebs, "Joint Criminal Enterprise" (2010) 73 M.L.R. 578, 588. Common purpose was, however, useful historically to found
} 
foreseen the possibility that D2 might commit Offence B in furtherance of Offence A. The Privy Council confirmed this contemplation/foresight version of PAL in Chan Wing-Siu $v$ R. (1984), ${ }^{4}$ a decision developed by the House of Lords in R. v Powell and English (1997). ${ }^{5}$ The Supreme Court/Privy Council claimed in R. v Jogee and Ruddock (hereafter Jogee) that Chan Wing-Siu represented a "wrong turn". ${ }^{7}$ Consistent with a paper written in 2013 by Lord Toulson, who co-authored the unanimous judgment in Jogee, ${ }^{8}$ it was contended that before Chan Wing-Siu secondary liability required intentional encouragement or assistance ${ }^{9}$ of each of the principal's crimes. Foresight that a particular offence might be committed, it was alleged, was evidence of the required intention to encourage or assist that particular offence, not an independent fault element as Chan Wing-Siu decided. ${ }^{10}$ The Supreme Court/Privy Council claimed they were thus merely "correcting" the error in Chan Wing-Siu. This response enabled them to largely sidestep the constitutional question of whether the courts, or instead Parliament, should be responsible for changing the law. ${ }^{11}$

It will be argued here that, far from being an invention of the mid-1980s, PAL existed consistently, in some form, from at least the sixteenth century. ${ }^{12}$ Chan Wing-Siu was not an anomaly, but simply confirmation that PAL's limits had narrowed by the latter half of the twentieth century to require "subjective" contemplation of Crime B. Chan Wing-Siu was simply more intellectually honest regarding the true position of secondary parties relative to Offence B than previous cases had been. ${ }^{13}$ The House of Lords' later decision in Powell and English was even more so. Jogee was thus not mere common law housekeeping. It was substantive and significant reform of the law. This alternative view of legal history raises

\footnotetext{
"constructive" presence when physical presence was required for aiding and abetting: e.g. R. v Passey (1836) 7 Car. \& P. 282.

${ }^{4}[1985]$ A.C. 168.

${ }^{5}[1999] 1$ A.C. 1.

${ }^{6}$ [2016] UKSC 8; [2016] UKPC 7, [2016] 2 W.L.R. 681.

${ }^{7}$ ibid. at [3].

${ }^{8}$ R. Toulson, "Sir Michael Foster, Professor Williams and Complicity in Murder" in D.J. Baker and J. Horder (eds.), The Sanctity of Life and the Criminal Law: The Legacy of Glanville Williams (Cambridge 2013), 230 (hereafter Toulson, "Complicity").

${ }^{9}$ Parts of Jogee suggest that the secondary party must himself have the mens rea of the principal's offence(s) (e.g. at [72]), others that she simply has to intend to encourage or assist the principal's offence(s) (at [90]). The latter position is preferable: see $N C B v$ Gamble [1959] 1 Q.B. 11.

${ }^{10}$ This history does have academic support - see M. Dyson, "Letter to the Editor" [2016] Crim. L.R. 638, 638639.

${ }^{11}$ Jogee, at [85].

${ }^{12}$ PAL could be older - see J.M. Kaye, "The Early History of Murder and Manslaughter - Part II" (1967) 83 L.Q.R. 569, 579 (hereafter Kaye "Murder and Manslaughter").

${ }^{13}$ See, similarly, J.K.M. Smith, A Modern Treatise on Criminal Complicity (Oxford 1991), 210-211 (hereafter Smith, Complicity).
} 
afresh questions about the constitutional limits of judicial reform of the criminal law, i.e. “judicial activism”.

The majority of this paper is dedicated to presenting an account of PAL's development through the sixteenth to the twentieth centuries (Parts II-VI). Part VII explains briefly why this alternative history clears the way to seeing the constitutional concern raised by Jogee.

Before moving further, two caveats must be noted. First, most reported cases relevant to PAL involve homicide. The attendant rules on felony murder could thus have a distorting effect until their abolition in $1957 .{ }^{14}$ Secondly, the defendant was only permitted to speak in his defence in all cases by section 1 of the Criminal Evidence Act 1898. Beforehand, the ability of the courts to assess the defendant's "subjective" thought processes was limited, and thus reliance on "objective" factors was more commonplace. It is submitted that, if these caveats are borne in mind, it remains possible to doubt the Supreme Court/Privy Council's history of PAL.

\section{THE SIXTEENTH CENTURY}

The sixteenth century law on accessorial liability was undeveloped, ${ }^{15}$ but an early version of PAL is detectable. ${ }^{16}$ In $R . v$ Salisbury ${ }^{17}$ a servant joined in a fight involving his master (Offence A). During the fight, the master killed another combatant (Offence B). ${ }^{18}$ The servant was ignorant of his master's pre-existing plan to commit murder. ${ }^{19}$ The servant was held liable for manslaughter, because he was ignorant of the murderous plan, and also lacked the "malice prepense" ${ }^{20}$ required for murder. This decision was generous. ${ }^{21}$ In the mid-sixteenth century, the sole question appears to have been whether the collateral offending - even if unforeseeable - occurred in pursuit of the parties' common unlawful purpose. For example, in R. $v$ Herbert, ${ }^{22}$ a group was assembled by Herbert to steal from and fight Mansell, but

\footnotetext{
${ }^{14}$ This is not to mention the additional distorting effect of capital punishment, and changing judicial attitudes towards it.

${ }^{15}$ See J. Baker, The Oxford History of the Laws of England: Volume VI - 1483-1558 (Oxford 2003), 574-579 (hereafter Baker, Oxford History).

${ }^{16}$ On interpretational difficulties concerning older authorities, see Smith, Complicity, 210.

${ }^{17}$ (1553) 1 Plowd. 97.

${ }^{18} c f$. Kaye, "Murder and Manslaughter", 585.

${ }^{19}$ Salisbury's master meant to kill the deceased's master.

${ }^{20}$ i.e. premeditation - Baker, Oxford History, 555.

${ }^{21}$ See, also: Kaye, "Murder and Manslaughter", 586; Anon (1585) Godb. 64, 66.

22 (1556) 2 Dyer 128b. See, also, J. Baker (ed.), The Reports of Robert Dalison 1552-1558 (London 2007), 127128.
} 
apparently did not intend to kill anyone. A disturbance ensued, and a stone thrown by a member of Herbert's group (aimed at someone else) killed Mansell's sister. Half of the judges $^{23}$ thought that Herbert's group was liable for her murder, given its connection to their initial unlawful purpose. In essence, "if a man takes the risk of doing an unlawful act, he must take all the consequences of that act even though he had neither intended nor foreseen them". ${ }^{24}$ For the remaining judges, the group was liable for murder only if it was proved that Mansell's sister had come in defence of her brother, binding the murder to the group's initial unlawful purpose. If Mansell's sister had not sided with either party, then her death was a separate incident, and Herbert's group could be liable, at most, for manslaughter. The evidence could not resolve this factual issue, but the law was clear. ${ }^{25}$ Importantly, it is implicit in the approach of both groups of judges that, had the initial purpose of Herbert's group been lawful, there would not have been liability for murder or manslaughter, at least without evidence of actual encouragement or assistance being given to the stone thrower. ${ }^{26}$

The judges' approach in Herbert is consistent with PAL. A party to a common unlawful purpose could be liable for a collateral offence despite not intentionally assisting or encouraging it - the distinguishing mark of PAL. The reaches of this early PAL doctrine are, nevertheless, unclear. In murder cases, the felony murder rule removed any need for proof of fault with regard to killing. ${ }^{27}$ Even if no felony were commanded, however, a collateral murder would be the responsibility of all parties to the common purpose. ${ }^{28}$ Furthermore, although those who commanded "beatings" were responsible for collateral murders, an intention to beat was sufficient mens rea for murder at the time. ${ }^{29}$ Examples not involving murder are thus more useful.

One rare example of a (hypothetical) case not involving murder is provided in Plowden's commentary on R. v Saunders and Archer. ${ }^{30}$ For Plowden, it was "reasonable" to hold secondary parties liable for what "follows from [the secondary party's procurement of the principal's offence], but not from any other distinct thing". ${ }^{31}$ Collateral crimes were not always "distinct things", an approach that stretched beyond murder. For instance, if a person

\footnotetext{
${ }^{23}$ Technically judges, Serjeants and law officers.

${ }^{24}$ Kaye, "Murder and Manslaughter", 580.

${ }^{25}$ cf. R. v Gnango [2010] EWCA Crim 1691, [2011] 1 W.L.R. 1414, at [26].

${ }^{26}$ Kaye, "Murder and Manslaughter", 582.

${ }^{27}$ Noted in Jogee, at [23].

${ }^{28}$ See, e.g., R. v Wright (1562) Gell's Reports, reproduced in J.H. Baker (ed.), Reports from the Lost Notebooks of Sir James Dyer: Vol. 2 (London 1994), 435.

${ }^{29}$ Baker, Oxford History, 555-556.

${ }^{30}$ (1573) 2 Plowd. 473. See, further, J.H. Baker, " $R v$ Saunders and Archer (1573)" in P. Handler, H. Mares and I. Williams (eds.), Landmark Cases in Criminal Law (Oxford, forthcoming).

${ }^{31}$ R. v Saunders and Archer (1573) 2 Plowd. 473, 475.
} 
commanded robbery (Offence A), and more severe violence was used against the victim (Offence B), the commander was liable for both offences. ${ }^{32}$ No explanation regarding the connection between the offences is given, so no intention to encourage Offence B is mentioned.

Plowden's "distinct things" lacked a "connection or affinity" with the secondary party's command. ${ }^{33}$ For instance, if the defendant specified that V1's house should be burned and the principal deliberately burned down V2's house, the defendant would not be a secondary party to the property damage. The principal's offence would be "another distinct thing, to which [the commander] gave no assent nor command". ${ }^{34}$ Similarly, if the parties' original unlawful purpose was accomplished, and the collateral offence occurred afterwards, distinct evidence of assistance or encouragement in relation to the collateral offence had to be proved. ${ }^{35}$

It is not clear how far beyond commanding (counselling and procuring, in modern terms $)^{36}$ Plowden's comments went, or what the "assent" he referred to involved. These points do not harm the thesis that PAL existed in the sixteenth century. It did not appear necessary for there to be, even in homicide cases, a common purpose to additionally resist by force opposition to the plan, although brief references to such resolutions appear. ${ }^{37}$ As will be seen below, the common purpose to resist opposition was to reappear at various points in history, and was capitalised upon in Jogee.

\section{THE SEVENTEENTH CENTURY}

The focus on collateral offence committed in pursuit of the parties' common purpose was maintained, as far as the reported sources suggest, in the early-to-mid seventeenth century authorities - beyond, it appears, procurement cases: "when several men joyn in an unlawful act they are all guilty of whatever happens upon it... For a man must take heed how he joineth in any unlawful act as fighting is, for if he doth, he is guilty of all that follows." 38

\footnotetext{
${ }^{32}$ ibid.

${ }^{33}$ ibid.

${ }^{34}$ ibid.

${ }^{35}$ Kaye, "Murder and Manslaughter", 594.

${ }^{36}$ See E. Coke, The Second Part of the Institutes of the Laws of England (London 1642), 182.

${ }^{37}$ See, e.g., Snook's Case (1560) Sav. 67. Although it may have been a "necessary assumption" that such a resolution existed (Baker, Oxford History, 556), the cases are unclear. See, further, R. v Griffith (1553) 12 Plowd. 97; Lord Dacre's Case (1535) Moore K.B. 86.

${ }^{38}$ R. v Stanley (1662) Kelyng J 86, 87. cf. R. v Hyde (1672) 1 Hale P.C. 537.
} 
The law was, however, beginning to narrow. A useful contrast can be drawn between two hypothetical cases addressed by the Court of King's Bench in $1692:^{39}$

3. Whether if A. heard B. threaten to kill C. and some days after A. shall be with B. upon some other design, where C. shall pass by, or come into the place where A. and B. are, and C. shall be killed by B. A. standing by, without contributing to the fact, his sword not being drawn, nor any malice ever appearing on A.'s part against C. whether A. will be guilty of the murder of C.?

Ans. A. in this case would not be guilty either of murder or manslaughter.

Here, there is no common unlawful purpose, and so even the nascent PAL doctrine recognised in the sixteenth century would be inapplicable: actual assistance or encouragement of the murder (presumably provided intentionally) would be required in such a case.

5. Whether a person, knowing of the design of another to lie in wait to assault a third person, and accompanying him in that design, if it shall happen that the third person be killed at that time, in the presence of him who knew of that design, and accompanied the other in it, be guilty in law of the same crime with the party who had that design, and killed him, though he had no actual hand in his death?

Ans. If a person is privy to a felonious design, or to a design of committing any personal violence, and accompanieth the party in putting that design in execution, though he may think it will not extend so far as death, but only beating, and hath no personal hand, or doth otherwise contribute to it than by his being with the other person, when he executeth his design of assaulting the party, if the party dieth, they are both guilty of murder. For by his accompanying him in the design, he shews his approbation of it, and gives the party more courage to put it in execution; which is an aiding, abetting, assisting and comforting of him, as laid in the indictment.

The answer to question 5 is reminiscent of the two-offence analysis employed in modern PAL cases. A is intentionally encouraging B only to beat C (Offence A), yet he is liable for C's murder (Offence B). ${ }^{40}$ An intention to beat was, however, sufficient fault for murder at the time, ${ }^{41}$ and other seventeenth century authorities suggest that ignorance of the principal's plan to kill might (as in Salisbury) relieve the defendant of secondary liability for murder. ${ }^{42}$ Less instructive still is the alternative example where A intentionally encouraged B to commit a felony, because of the felony murder rule.

It is worth noting, before proceeding, that the court viewed question 5 as being an example of aiding and abetting; the encouragement for Offence B came from supporting the principal's plan to commit Offence A. The long-running dispute about whether PAL was truly

\footnotetext{
${ }^{39}$ Lord Mohun's Trial (1692) Holt, K.B. 479, 480.

${ }^{40}$ See, similarly, E. Coke, The Third Part of the Institutes of the Laws of England (London 1644), 51.

41 ibid.

${ }^{42}$ E.g. R. v Thody (1673) 1 Freem. 514.
} 
a form of aiding and abetting, or a distinct head of liability, does not appear to have got off the ground by this point in history. It will, however, be returned to at various points below.

Hale, writing in the 1670s (albeit his work was not published until the 1730s), also includes examples structurally reminiscent of PAL, but restricts secondary liability - at least in procurement and counselling (accessory before the fact) cases - to "objectively" probable results of the initial common purpose. First, "If A. command B. to beat C., and he beat him so that he die thereof, it is murder in B. and A." ${ }^{43}$ No explicit connection was required between the beating and the death. By contrast: "If A. counsel or command B. to beat C. with a small wand or rod, which could not in all human reason cause death, if B. beat C. with a great club, or wound him with a sword, whereof he dies, it seems, that A. is not accessory, because there was no command of death, nor of any thing, that could probably cause death, and B. hath varied from the command in substance, not in circumstance." 44 The "compass of [the parties'] original intention" 45 - could stretch only so far, and its outer limit was, at least in relation to accessories before the fact (counsellors and procurers), probable collateral offending. ${ }^{46}$

Importantly, given later developments, Hale maintains that, for principals in the second degree (aiders and abettors), certain collateral offences were presumed to be within the parties' common purpose to commit felonies: if a group embarks on a plan to steal deer, "the law presumes they came all with intent to oppose all that should hinder them in that design, and consequently when one kild the keeper, it is presumed to be the act of all, because pursuant to that intent... tho there were no express intention to kill any person in the first enterprise... the law presumes they come to make good their design against all opposition". ${ }^{4}$ If the group's joint purpose was lawful, however, secondary liability for murder required proof it was actually encouraged or assisted. ${ }^{48}$ Embarking on Offence A was itself, then, the basis for a presumption that opposition to Offence A would be met with force sufficient to ground a conviction for murder (Offence B) if death resulted. In other words, Hale's writing about the law in the 1670s is compatible with the existence of PAL, even if a distinction between accessories before the fact (probability test) and principals in the second degree (the scope of the common purpose, with - at least in felonies - additional presumed force, test) was visible.

\footnotetext{
${ }^{43}$ M. Hale, Historia Placitorum Corona, vol. 1 (London 1736), 435, 617 (hereafter Hale, Historia).

${ }^{44}$ ibid. 436.

${ }^{45}$ ibid. 444.

${ }^{46}$ ibid. 443.

${ }^{47}$ ibid, 443-444 (emphasis added). cf. W. Hawkins, The Pleas of the Crown, 4th ed. (London 1762), vol. 2, ch. 29 , s. 8.

${ }^{48}$ Hale, Historia, 444.
} 
The law's approach continued to narrow during the eighteenth century.

\section{THE EIGHTEENTH CENTURY}

In $R . v$ Plummer, Holt CJ said that, if a group of smugglers were to be liable for the murder of an officer committed by one of their number: ${ }^{49}$

The killing must be in pursuance of that unlawful act, and not collateral to it. As for the purpose, if divers come to hunt in a park, and the keeper commands them to stand, and resists them; if one of the company kills the keeper, it is not only murder in him, but in all the rest then present, that came upon that design, for it was done in pursuance of that unlawful act...

But suppose that they coming into the park to hunt, before they see the keeper, there is an accidental quarrel happens amongst them, and one kills the other, it will not be murder but manslaughter; and in the rest that were not concerned in that quarrel it will not be felony. [Emphasis added.]

The implication is that no knowledge of the principal's further offence was necessary if it was committed in pursuance of a common unlawful purpose. The (in fact) collateral offence was only (in law) a collateral offence if it was not done in pursuance of the initial unlawful purpose. This inclusion of what were, in fact, collateral offences within the parties' "common purpose" was an intellectual dishonesty that was to dog judgments until Chan Wing-Siu.

In R. v Ashton, Holt CJ gave an additional example: "Two, three or more, are doing an unlawful act, as abusing the passers-by in a street or highway, if one of them kill a passer-by it is murder by all". ${ }^{50}$ There is no mention of the need for a common plan to commit murder, or even contemplation that murder might happen. Furthermore, there is no felony. There is a simple connection between the unlawful abuse (Offence A) and the murder (Offence B) that flows from it. This is, structurally, reminiscent of PAL. A similar, two-step analysis can be applied to $R$. $v$ Wallis, where it was suggested that: "If a man begins a riot... and the same riot continue, and an officer is killed, he that began the riot... is a... murderer; though he did not do the fact". ${ }^{51}$ Again, liability for Offence B (murder) was imposed on the basis that it was an incident of the common purpose to commit Offence A (affray/rioting).

Assuming the initial common purpose of the parties was illegal, ${ }^{52}$ it was only if murder was not connected to Offence $\mathrm{A}-$ as in R. v Hodgson, ${ }^{53}$ where a boy, unconnected

\footnotetext{
${ }^{49}$ (1701) Kel. J. 109, 113-114.

${ }^{50}$ (1703) 12 Mod. 256, 256.

51 (1703) 1 Salk. 334, 335.

${ }^{52}$ cf. R. v Borthwick (1779) 1 Doug. 207.

53 (1730) 1 Leach 6.
} 
with an affray, was killed - that liability for Offence B was ruled out in the absence of explicit assistance or encouragement. Holt CJ and Pollexfen CJ thought that the group in Hodgson was to be convicted of murder partially on the basis that they had armed themselves with offensive weapons. ${ }^{54}$ Holt CJ delivered the opinions in Plummer and Ashton, so it is plausible that the weapons were relevant to establishing the probable dangers posed by the original unlawful purpose, suggesting that the killing was committed in furtherance of that purpose, and was not a distinct act.

The law's approach thus does not appear to have moved on a great deal by the 1730s. Contemporary secondary literature does, however, suggest that the probability of collateral offending remained important, at least sometimes. Foster ${ }^{55}$ corroborates Hale's comments about actions in pursuit of criminal ventures in cases of counselling and procuring: if "A. adviseth B. to rob C., he doth rob him, and in so doing either upon resistance made, or to conceal the fact, or upon any other motive operating at the time of the robbery, killeth him. A. is accessory to this murder." ${ }^{56} \mathrm{He}$ explains that: "The advice, solicitation, or orders in substance were pursued, and were extremely flagitious on the part of A. The events, though possibly falling beyond his original intention, were in the ordinary course of things the probable consequences of what B. did under the influence, and at the instigation of A."57 In cases involving counsellors and procurers, the focus was thus on what was probable, rather than intended. It must be accepted that, when Foster was writing, probability and intention would have been conceptually closer than they are nowadays, yet Foster distinguishes intention from probability. This unsettles the assumption in Jogee that a "subjective" version of Foster's probability test would be the modern concept of intention. ${ }^{58}$ The "subjective" equivalent of "objective" probability, i.e. foreseeability, is presumably "subjective" foresight of the relevant probability, which is (almost) what Chan Wing-Siu endorsed.

The probability test certainly softened the law's approach: a bare felony (robbery) was not enough to affix liability for murder - death had to be a probable result. This perhaps explains an awkward aspect of Foster's account. ${ }^{59}$ He cites a 1697 case, where three soldiers went to steal apples. ${ }^{60}$ One soldier was confronted by the orchard owner's son and murdered him. The other soldiers were acquitted of murder. They were engaged in "small inconsiderate

\footnotetext{
${ }^{54}$ At 6.

${ }^{55}$ See Jogee, at [18]-[20].

${ }^{56}$ M. Foster, Crown Law (Oxford 1762), 370 (hereafter Foster, Crown Law). See, too, W. Blackstone, Commentaries on the Laws of England: Book the Fourth, 7th ed. (Oxford 1775), 37.

${ }^{57}$ Foster, Crown Law, 370 (emphasis in original).

58 Jogee, at [73].

${ }^{59}$ cf. Toulson, "Complicity", at p. 237.

${ }^{60}$ Foster, Crown Law, 353.
} 
trespass", and it was not clear that they had a "general resolution against all opposers". ${ }^{61}$ This result might appear puzzling: Offence B (murder) seems to have been committed in pursuit of Offence A (stealing apples), and that was enough - it appears - to found secondary liability in the seventeenth century. But the answer to this quandary might be probability - if that test was to be applied beyond accessories before the fact. In the soldiers' case, murder was not a probable consequence, given the "minor" nature of the common purpose to steal apples. This analysis (which is, it is submitted, less ahistorical than an alternative one based on "conditional intention") could be used to explain away the orchard example, and indeed it later was. $^{62}$

By the end of the eighteenth century, then, the question of whether Offence B was a probable consequence of the common intent to commit Offence A had begun to assume importance, most clearly in cases of accessories before the fact, but perhaps also in cases of principals in the second degree. Admittedly, what the parties knew (for example, whether the principal (in the first degree) was armed or not) or had planned was relevant to the probability assessment. ${ }^{63}$ The Supreme Court/Privy Council agreed with this general picture in Jogee, ${ }^{64}$ but alleged that things changed markedly in the nineteenth century.

\section{THE NINETEENTH CENTURY}

In Jogee, it was contended that: ${ }^{65}$

Cases in the nineteenth century showed ... a significant change of approach. It was no longer sufficient ... to prove that the principal's conduct was a probable consequence, in the ordinary course of things, of the criminal enterprise ... The prosecution had to prove that it was part of their common purpose, should the occasion arise.

The Supreme Court/Privy Council is right about the intellectual muddle the courts created in the nineteenth century (finding the collateral offence to be part of the parties' "common purpose" when it was, in fact, a departure from it). That conclusion does not, however, ground a requirement that the defendant had to intend to encourage or assist every one of the

\footnotetext{
${ }^{61}$ ibid.

${ }^{62}$ R. v Jackson (1857) 7 Cox. C.C. 357, discussed below. $c f$. W. Wilson and D. Ormerod, "Simply Harsh to Fairly Simple: Joint Enterprise Reform" [2015] Crim. L.R. 3, 8 (hereafter Wilson and Ormerod, "Joint Enterprise Reform").

${ }^{63}$ K.J.M. Smith, "Criminal Law" in W. Cornish et al. (eds.), The Oxford History of the Laws of England: Volume XIII: 1820-1914 Fields of Development (Oxford 2010), 1 at p. 291 (hereafter Smith, “Criminal Law”).

${ }^{64}$ At [18], [20].

${ }^{65}$ Jogee, at [21].
} 
principal's offences if he was to be a secondary party to them. This becomes clear when a full view of the cases is taken.

East suggests that the presumption of a resolution to resist opposition when a felony was embarked upon remained in $1803,{ }^{66}$ but also mentions the secondary party's "contemplation" of the principal's crime(s). ${ }^{67}$ It is not clear what relevance such "contemplation" had to determining the liability of parties - or indeed what "contemplation" was taken by East to entail - but it is significant that even by 1803 the language of "contemplation" was used in relation to secondary liability. As demonstrated below, "contemplation" became very important in the early twentieth century, and was important to Chan Wing-Siu itself.

During the nineteenth century, the presumption regarding resistance gave way to the necessity of proof that the parties' "common purpose" included such contingencies, ${ }^{68}$ but caution must be exercised when pondering whether this required proof that the parties actually shared a common intention. Some authorities might support this jump. In $R$. $v$ White, it was held that: "if the prisoners came with the same illegal purpose, and both determined to resist, the act of one would fix guilt upon both...". ${ }^{69}$ Rather than presuming such a determination existed, the court found that White's running away as soon as the alarm was raised secured his acquittal for the principal's violent crime. The Supreme Court/Privy Council is thus right insofar as it does appear that the parties would need to be proved to have "determined" to resist opposition with force. But it remains something of a leap from the common "determination" mentioned in White to a discrete intention to assist or encourage all of the principal's offences. It is not certain how far White departed from the earlier probability model. Lawyers at the time still presumed natural and probable consequences of actions to be "intended". ${ }^{70}$ It would thus be unwise to read statements about "determination" to be broadly synonymous with intention, and then use that to support a thesis involving the modern understanding of intention.

The concept of a common resolution to resist opposition was opaque. The first edition of Russell on Crime (1819) states that principals in the second degree (aiders and abettors)

\footnotetext{
${ }^{66}$ E.H. East, A Treatise of the Pleas of the Crown (London 1803), 257.

${ }^{67}$ ibid. 259.

${ }^{68}$ Reforms of the criminal trial in the early nineteenth century facilitated a sharper focus on proof of "subjective" fault. See R.A. Duff et al., The Trial on Trial: Vol. 3 - Towards a Normative Theory of the Criminal Trial (Oxford 2007), 46-48.

${ }^{69}$ (1806) R. \& R. 99, 101.

${ }^{70}$ R. v Dixon (1814) 3 Mau. \& Sel. 11. The strength of the presumption wavered over time - see K.J.M. Smith, Lawyers, Legislators and Theorists: Developments in English Criminal Jurisprudence 1800-1957 (Oxford 1998), 166-171 (hereafter Smith, Lawyers).
} 
must have "a general resolution against all opposers ... whether such resolution appears ... to have been actually and explicitly entered into by the confederates, or may be reasonably collected from their number, arms, or behaviour, at or before the scene of the action". ${ }^{71}$ The "resolution" to resist opposition could thus be tacit, but it is unclear what such a "resolution" amounted to. If this "resolution" was a synonym for intention, it is noteworthy that the word "resolution" remained unchanged in the text by $1950,{ }^{72}$ when the law's approach to fault elements (and principally intention) had begun to solidify. ${ }^{73}$ Significantly, when assessing the Supreme Court/Privy Council's historical view, the common purpose scenario was juxtaposed in the 1819 edition with liability on the basis of having "actually aided and abetted him in the fact", ${ }^{74}$ suggesting that PAL was becoming at least a special variety of aiding and abetting, if not a discrete doctrine, by the early nineteenth century.

The cases were similarly unclear about how a common "resolution" to resist opposition was proved. For instance, in R. v Hawkins, ${ }^{75}$ some poachers beat up a gamekeeper. The principal returned later and robbed the gamekeeper. The common purpose was assumed to be "to kill game, and perhaps to resist the keepers". ${ }^{76}$ The use of the word perhaps suggests that, even when violence was actually used, the courts might not find that a common purpose to use it had existed, but this idea is not explored further.

Aside from concerns over what a common "resolution" to resist opposition involved, and how it was to be proved, it was not always insisted upon. In Redford v. Birley and Others, Holroyd J noted that if a group's purpose was lawful, it would not be liable for the principal's crimes unless actual aiding and abetting were proved, but: ${ }^{77}$

If persons go together, go united in an unlawful design, to commit a felony, or a breach of the peace, and, in the course of effecting that purpose any one does an act in pursuit of the common purpose, they are all answerable because that which they set about, upon a common design, was originally unlawful.

\footnotetext{
${ }^{71}$ W.O. Russell, A Treatise on Crimes and Misdemeanors, vol. 1 (London 1819), 31-32 (hereafter Russell, Treatise). cf. J. Chitty, A Practical Treatise on the Criminal Law (Philadelphia 1819), 174. It was noted that a murder conviction would be "particularly" available in cases involving a common purpose to resist opposition, suggesting such a common purpose was not a necessary condition, in J.F. Archbold, A Summary of the Law Relative to Pleading and Evidence in Criminal Cases (London 1822), 397. That part of the text remained unchanged into the 1920s: e.g. H. Delacombe and R.E. Ross, Archbold's Pleading, Evidence \& Practice in Criminal Cases, 26th ed. (London 1922), 1438.

${ }^{72}$ J.W.C. Turner, Russell on Crime: On Felonies and Misdemeanors, vol. 2, 10th ed. (London 1950), 1852.

${ }^{73}$ See Smith, Lawyers, ch. 9.

${ }^{74}$ Russell, Treatise, 33 (emphasis added).

75 (1828) 3 Car. \& P. 392.

${ }^{76}$ At 393.

${ }^{77}$ (1822) 3 Stark. 76, 97. See, also, 114-115.
} 
The probability of Offence B's occurrence is not noted in Reford $v$ Birley and Others (perhaps suggesting that approach was still restricted to accessories before the fact), never mind the resolution to resist opposition. ${ }^{78}$ Holroyd J's statement would not look out of place in the early seventeenth century.

The law's approach to most issues at the time was inconsistent, ${ }^{79}$ and so discrepancies are not unexpected. The suggestion in Jogee is that the law began to solidify in R. v Collison $(1831):{ }^{80}$

To make the prisoner a principal, the jury must be satisfied that, when he and his companion went out with a common guilty purpose of committing the felony of stealing apples, they also entertained the common guilty purpose of resisting to death, or with extreme violence, any persons who might endeavour to apprehend them; but if they had only the common purpose of stealing apples, and the violence of the prisoner's companion was merely the result of the situation in which he found himself, and proceeded from the impulse of the moment, without any previous concert [the secondary party would be acquitted]. [Emphasis added.]

Collison is similar, factually, to Foster's orchard example, and suffers from the same difficulty concerning the probability of murder being committed (if that test had begun to filter into aiding and abetting). Garrow B's judgment is, however, supportive of the Supreme Court/Privy Council's historical thesis that the common purpose, in murder cases, had to include (if conditionally) "severe violence". ${ }^{81}$ It is not clear, though, what Garrow B meant by "entertained the common guilty purpose", and what evidence would have established the necessary "concert". The Supreme Court/Privy Council's reading is that an intention to assist or encourage severe violence would be required. But "entertaining" the purpose of committing a collateral offence could equally have meant contemplating the risk of a member of the enterprise needing to use force in pursuit of the common purpose, and continuing regardless. That reading of Collison would be consistent with the modern cases on PAL, such as Chan Wing-Siu, insofar as mere contemplation of Offence B does not entail an intention to encourage or assist Offence B (as the Supreme Court/Privy Council noted correctly).

Other statements from that period are similarly opaque. In $R . v$ Duffey, ${ }^{82}$ decided a year before Collison, an important question was whether the secondary party was "cognizant"

\footnotetext{
${ }^{78}$ cf. E.E. Deacon, A Digest of the Criminal Law of England, vol. 2 (London 1831), 907 (emphasising both the probability of Offence B and the defendant's "contemplation" of what the principal might do).

${ }^{79}$ R. Cross, "The Reports of the Criminal Law Commissioners (1833-1849) and the Abortive Bills of 1853" in P.R. Glazebrook (ed.), Reshaping the Criminal Law: Essays in Honour of Glanville Williams (London 1978), 5 at p. 7.

${ }^{80}$ (1831) 4 Car. \& P. 565, 566.

${ }^{81}$ Jogee, at [22].

82 (1830) 1 Lewin 194.
} 
of the principal's collateral offence and "concurring" in it. ${ }^{83}$ It was not clear what the relevant "cognition" and "concurrence" required.

Collison's resolution to use force appears in other nineteenth century cases, but the matter of what could establish it remained unclear. ${ }^{84}$ In $R . v$ Scotton, ${ }^{85}$ the defendants (poachers) were not liable as the principal was alone at the time of the shooting, and there was no evidence that they had intentionally helped or encouraged him to shoot. This decision might support a necessary requirement of help or encouragement, provided intentionally supporting the historical argument in Jogee. The judgment in Scotton is, however, short, and the relevance of the alleged secondary parties' absence might have been that the original common purpose of the parties to poach was exhausted, rendering the principal's shooting a gamekeeper his responsibility only. That principle can exist alongside a form of PAL, which simply imposed liability for unintended collateral offences committed in pursuit of the original unlawful purpose.

R. v Macklin and Murphy ${ }^{86}$ suggests the Collison approach was, anyway, generous to defendants: ${ }^{87}$

[I]f several persons act together in pursuance of a common intent, every act done in furtherance of such intent by each of them is, in law, done by all. The act, however, must be done in pursuance of the common intent. If several men were to intend and agree together to frighten a constable, and one were to shoot him through the head, such an act would affect the individual only by whom it was done.

There is no requirement, here, to show that a collateral offence was more than a probable consequence (assuming that deliberate, as opposed to panicked, shooting is not a probable consequence of frightening) of the execution of the common purpose. All that is clear is that an action completely divorced from the initial "common intent" was not something to which secondary liability would attach. If one is not distracted by the word "intent" (still used loosely at the time), this view is consistent with the older authorities, and the existence of a (harsh) PAL doctrine.

Similarly, in R. v Howell, Littledale $\mathrm{J}$ told the jury that: ${ }^{88}$

\footnotetext{
${ }^{83}$ At 194. See, too, the headnote in R. v Cruse (1838) 8 Car. \& P. 541.

${ }^{84}$ E.g. R. v Doddridge (1860) 8 Cox. C.C. 335.

${ }^{85}$ (1844) 5 Q.B. 493.

${ }^{86}$ (1838) 2 Lewin 225 (recognised as the genesis of PAL in Assisting and Encouraging Crime (Law Com. C.P. No. 131, 1993), para. 1.13).

${ }^{87}$ At 226.

${ }^{88}$ (1839) 9 Car. \& P. 437, 448.
} 
[A]ll those who assemble themselves together with a felonious intent, the execution thereof causes either the felony intended or any other to be committed, or with intent to commit a trespass, the execution whereof causes a felony to be committed, and continuing together abetting one another until they have actually put their design into execution [were liable]. [Emphasis added.]

There is, here, no requirement of a common design beyond the first felony, or "trespass" (misdemeanor). Littledale $\mathrm{J}$ continued that, "It appears ... that there are cases in our law, where persons setting out engaged in a particular object, and in promotion of that object a felony was committed, though not originally intended, and where death ensued... all have been found guilty of murder or manslaughter" ${ }^{89}$ If what marks PAL out is the fact that the secondary party is held liable for Offence $\mathrm{B}$, without the need to have intended to encourage or assist Offence B, then Littledale $\mathbf{J}$ appears to be explaining PAL in 1839. (Indeed, the felony murder rule cannot be used as an explanation here, as the common purpose seems to have led to a separate felony which led to death.) Other cases from that period can be analysed similarly. ${ }^{90}$ If Collison did in fact require an actual intention to assist or encourage the collateral offence, then this requirement was applied inconsistently. ${ }^{91}$

Bramwell B's direction to the jury in $R$. $v$ Jackson raises further doubts about the necessity of an intention to encourage or assist Offence $\mathrm{B}:{ }^{92}$

[I]f two persons are engaged in the pursuit of an unlawful object ... and in the pursuit of that common object, one of them does an act which ... amounts to murder in him, it is murder in the other also. The cases which have been referred to by the prisoner's counsel [Howell, and Foster's orchard example] may be explained in this way. The object for which the parties went out was comparatively a trifling one, and it is almost impossible to suppose that if one had committed a murder while engaged in pursuit of such an object, the act could have been done in furtherance of the common object they had in view, which was comparatively so unimportant.

In short, the probability of violence being used was relevant not to an intention to encourage or assist it, but simply in working out whether it was committed in pursuit of the original common purpose.

Further support for this view comes from R. v Harrington, ${ }^{93}$ where Martin B simply asked the jury if the death had occurred in pursuit of the common purpose to commit a breach

\footnotetext{
${ }^{89}$ At 450 (emphasis added).

${ }^{90}$ See, e.g.: R. v Bowen (1841) Car. \& M. 149 (the jury indicated that the secondary party intended to encourage the collateral crime, but were not told this was a necessary ingredient of liability); R. $v$ Harvey and Caylor (1843) 1 Cox. C.C. 21; R. v Cooper (1846) Q.B. 533.

${ }^{91}$ See, similarly: Smith, "Criminal Law" at p. 292; Smith, Complicity, 211.

92 (1857) 7 Cox C.C. 357.

93 (1851) 5 Cox. C.C. 231.
} 
of the peace and assault. Harrington was cited in the 1896 edition of Russell on Crime as an example of when a common purpose to resist oppressors was established, ${ }^{94}$ when there is no mention in the report of any purpose to do more than breach the peace and commit an assault. It is at least possible, then, that the common "resolution" was, in fact, determined by something other than (so to speak) actual intention, perhaps even the probability assessment that was already employed in relation to accessories before the fact. This was muddled by talk of probable consequences being within a "common purpose", which meant some collateral (i.e. unintended) offences were artificially brought within a "common purpose" that did not exist factually. This confusion is not unexpected. Intention would have been presumed on the basis of probable consequences of the defendant's acts, and so references to "resolutions" or "intentions" must be read in that light. It was certainly not clear, by the mid-nineteenth century, that anything more demanding than contemplation of the principal's probable collateral crime was required. ${ }^{95}$ Even contemplation might have been unnecessary, if collateral offending was probable.

The second half of the nineteenth century, following the passing of the Accessories and Abettors Act 1861, saw little clarity added. In $R$. v Franz, ${ }^{96}$ the jury was directed that it had to be sure that, in the light of all the evidence, a murder was committed to enable the planned burglary, or any other felony, before the parties were all liable for it as secondary parties. The reporters record that the doctrine that simply being involved in the burglary was enough to secure liability for additional offences was "long since exploded". ${ }^{97}$ But that doctrine, influenced strongly by the harshest incarnation of the felony murder rule, had since been supplemented by ones asking if the collateral offence was in pursuit of the common purpose and, at least in the cases of counselling and procuring, one asking whether the collateral offending was a probable outcome of pursuing the common purpose. Even if the reporters' posited "active or passive" participation in the collateral crime was meant as an additional ingredient of liability, it is not clear what it required. Could it be satisfied by contemplation of the need to cause such injury, as some previous cases can be read to suggest? Finally, it will be noted that the "resolution" in Franz (to inflict injury) is less demanding than the one in Collison (to use "extreme violence" or kill). ${ }^{98}$ A two-stage analysis

\footnotetext{
${ }^{94}$ H. Smith and A.P.P. Keep, A Treatise on Crimes and Misdemeanors, vol. 1, 6th ed. (London 1896), 168-169.

${ }^{95}$ See, further, R. v Price and Others (1858) 8 Cox. C.C. 96, 96.

${ }^{96}$ (1861) 2 F. \& F. 580.

${ }^{97}$ At 580. See, too, R. v Caton (1874) 12 Cox. C.C. 624, 625.

${ }^{98}$ See, too, R. v Lee (1864) 4 F. \& F. 63, 67.
} 
of Franz in terms of Offence A (injury) and Offence B (murder) is thus possible, suggesting it was not necessarily the burglary doing the work in establishing liability for Offence B.

Other authorities are harder to explain. For example, the footnoted commentary to $R . v$ Luck explains that the law's approach was more "humane" by 1862, because there had to be "a common design to commit a felony, and a felony homicidal in nature and likely to lead to homicide". ${ }^{99}$ Similarly, in $R$. v Turner, Channell B held that there must be a common purpose to use "murderous violence" before all parties could be liable for murder. ${ }^{100}$ There is still no indication, however, of how these cases built on the approach developed in the eighteenth century. The footnote in Luck speaks, for example, of felonies "likely to lead to homicide", suggesting that a probability focus was beginning to seep into cases involving principals in the second degree. Turner is harder to square with a probability-based analysis, but the matter of how a common purpose to use "murderous violence" was to be proved was unaddressed. All that was clear was that if the common purpose was to beat the victim, but the principal produced and used a knife, which the other parties did not know about, only the principal was liable for murder. ${ }^{101}$ That analysis is consistent, however, with a probability-based account of PAL: murder was less likely to flow from a beating than from a knife attack.

Later cases are, admittedly, difficult to fit into the probability assessment model of PAL, suggesting it might have remained limited to counselling and procuring. In R. v Skeet, Pollock CB noted that there could be secondary liability "where all the parties were aware that deadly weapons are taken with a view to inflict death or commit felonious violence, if resistance is offered". 102 "Awareness" is, however, a loose term. ${ }^{103}$ A person is not only aware of a possible outcome if she intends that possible outcome (I can be aware that someone might die if I $x$ simply by believing that to be a possible, if unlikely, result of $x$-ing). This casts doubt on the claim in Jogee that a discrete intention to assist or encourage the principal's collateral offending was required. Mere awareness was apparently sufficient to establish a "felonious design to carry out the unlawful purpose at all hazards, and whatever may be the consequences", ${ }^{104}$ suggesting that the "common design/intention" was (still) a construct, and its limits were set sometimes by probability and other times by contemplation. ${ }^{105}$

\footnotetext{
99 (1862) 3 F. \& F. 483, 486.

100 (1864) 4 F. \& F. 339, 339.

101 At 341 .

102 (1866) 4 F. \& F. 931, 936.

${ }^{103}$ See F. Stark, Culpable Carelessness: Recklessness and Negligence in the Criminal Law (Cambridge 2016), ch. 4.

${ }^{104}$ Skeet, at 937.

105 cf. Jogee, at [24].
} 
The way in which Skeet was interpreted in contemporary secondary sources is instructive. For example, the 1867 edition of Archbold states that: "it is not sufficient that the common purpose is merely unlawful; it must either be felonious, or if it be to commit a misdemeanor, then there must be evidence to show that the parties engaged intended to carry it out at all hazards". ${ }^{106}$ The use of "either" here suggests that if Offence A was a felony, then, liability for murder could flow in the absence of a common resolve to resist at all costs (perhaps a simple application of felony murder). There was thus no universal requirement of intention to assist or encourage collateral offending. If this was an erroneous statement of the law, it was not corrected, even by the time of the $26^{\text {th }}$ edition, published in $1922 .^{107}$

The Supreme Court/Privy Council based its account of the nineteenth century law on only five of the above-mentioned cases (Collison, Macklin, Luck, Turner and Skeet). Enough has been done to suggest that these cases were "exceptional", 108 "progressive" ${ }^{109}$ statements of the law, unclear in their precise implications, and unrepresentative of the entirety of contemporary jurisprudence. Indeed, by the close of the nineteenth century, it appeared that probability/foreseeability was becoming a standard test, beyond cases of counselling and procuring. In 1877, for instance, Russell on Crime recorded that a party would be liable for collateral offences that he "ought to have known" would follow from the common purpose. ${ }^{110}$ Although perhaps "editorial kite-flying", ${ }^{111}$ this statement remained in subsequent editions and is found in the 1950 edition, edited by arch "subjectivist" J.W.C. Turner. ${ }^{112}$

The English attempts at codification also suggest that "objective" probability, rather than intention, was assuming core importance. ${ }^{113}$ The 1843 and 1846 reports of the Criminal Law Commissioners envisaged liability for collateral offences perpetrated "in pursuance of and in accordance with [the parties'] design" ${ }^{114}$ (but with no indication of what this required, in terms of proof), with a probability analysis remaining limited to counselling and

\footnotetext{
${ }^{106}$ W. Bruce, Archbold's Pleading and Evidence in Criminal Cases, 16th ed. (London 1867), 881.

${ }^{107}$ H. Delacombe and R.E. Ross, Archbold's Pleading, Evidence \& Practice in Criminal Cases, 26th ed. (London 1922), 1438.

${ }^{108}$ Smith, "Criminal Law" at p. 292.

109 Smith, Complicity, 214.

${ }^{110}$ S. Prentice, A Treatise on Crimes and Misdemeanors, vol. 1, 5th ed. (London 1877), 164.

${ }^{111}$ Smith, Complicity, 211-212; Smith, "Criminal Law" at p. 292.

112 J.W.C. Turner, Russell on Crime: A Treatise on Felonies and Misdemeanors, 10th ed. (London 1950), 1855. cf. Smith, Complicity, 213.

${ }^{113}$ See Smith, Complicity, 213. The importance of codes in understanding the contemporary view of secondary liability is emphasised in A.P. Simester, "The Mental Element in Complicity" (2006) 122 L.Q.R. 578, 596-598.

${ }^{114}$ Seventh Report of Her Majesty's Commissioners on Criminal Law (London 1843), art. 16; Second Report of Her Majesty's Commissioners on Criminal Law (London 1846), art. 12. The words in square brackets are present in the 1843 , but not the 1846 , version.
} 
procuring. ${ }^{115}$ By the 1879 Criminal Code (Indictable Offences) Bill, however, this distinction had collapsed: parties were liable for what they "ought to have been known to be a probable consequence of the execution of [their] common intention". ${ }^{116}$ This was apparently thought to be a statement of the contemporary legal position, ${ }^{117}$ but it is far clearer than the cases at the time were in its confirmation that probability was a general test.

The nineteenth century colonial codes also focus on probable collateral offending ${ }^{118}$ and what ought to have been foreseen by the parties as probable. ${ }^{119}$ These codes were also thought to be rationalisations of existing English law, ${ }^{120}$ suggesting further that probability was considered to be the overarching test in establishing whether a collateral offence was (at least in legal fiction, if not in fact) included within the parties' common purpose. Significantly, the Codes deal with ordinary accessorial liability separately from common purpose scenarios, rendering the argument that ordinary aiding and abetting could suffice for all scenarios (which is, ultimately, the Supreme Court/Privy Council's thesis) questionable.

It is submitted that, once a proper view is taken of the nineteenth century authorities, a "subjective" element (but not necessarily intention to encourage or assist all of the principal's offences, at least as the word intention is nowadays understood) was beginning to be insisted upon by some judges, but it was not consistently explained in terms of intention, rather than contemplation. Furthermore, intention was used loosely, and often in conjunction with probability assessments, in the nineteenth century. It is difficult to take much from them, and certainly very difficult, when everything is taken into consideration, to divine a consistent trend of authority requiring an intention to assist or encourage each of the principal's offences.

The next section will demonstrate that the twentieth century cases suggest a move to greater "subjectivity" (in conjunction with the defendant's ability to give evidence at trial), but not necessarily towards intentional encouragement or assistance of each of the principal's offences. It will be argued that the move was more clearly towards "subjective" foresight of collateral offences, culminating in Chan Wing-Siu.

\footnotetext{
115 Arts. 13, 10.

$116 \mathrm{cl} .71$.

${ }^{117}$ G.L. Williams, Criminal Law: The General Part, 2nd ed. (London 1961), 402 (n. 1) (hereafter Williams, Criminal Law). cf. Smith, Complicity, 211.

${ }^{118}$ E.g. Indian Penal Code (Act No. 45 of 1860), s. 111 (particularly illustration (c)); The Criminal Code Act 1899 (63 Vic. No. 9), s. 8 (Queensland).

${ }^{119}$ The Criminal Code 1892 (55-56 Vict. c. 29), s. 61(2) (Canada) (cf. R. v Logan [1990] 2 S.C.R. 731); Criminal Code Act 1893 (57 Vic. No. 56), s. 73(2) (New Zealand).

${ }^{120}$ Mendez [2010] EWCA Crim 516, [2011] Q.B. 876, at [29].
} 


\section{The Twentieth Century (TO Chan WinG-SiU)}

As in the nineteenth century, most early twentieth-century cases were vague on the requirements of secondary liability. ${ }^{121}$ The law's development in common purpose scenarios remained "erratic". ${ }^{122}$ Far from being directed precisely on the parties" "subjective" intentions, juries were still told to establish the scope of the parties' "unlawful design" with little (recorded) guidance on how to do so. ${ }^{123}$

Where guidance was given to juries about collateral offending, it does not necessarily support the Supreme Court/Privy Council's view of history. In R. v Pridmore, the trial judge directed the jury that the defendant was liable for collateral offences that "naturally follow" from pursuing an agreement to poach. Phillimore J disagreed, and suggested that there needed to be a common purpose that included the intention to resist opposition, rather than merely poach. ${ }^{125}$ Yet it remained unclear what was required to establish such a common purpose, and the trial judge's comments about the secondary parties' "realisation" of the principal's potential collateral offending were not criticised. Ultimately, the way in which the secondary party held his stick (aggressively, it appears) was taken to be evidence enough of the common purpose to use force. ${ }^{126}$

To add to the interpretational difficulties, it is unclear from Pridmore how much force the secondary party had to have (implicitly) appreciated was part of the common purpose. ${ }^{127}$ It is not clear that the "common purpose" (however established) had to stretch to serious violence or lethal force in order to affix liability for murder, as Collison had suggested. If it did not have to stretch that far, then, structurally, Pridmore can be read consistently with the existence of PAL: intentional encouragement of the use of (some) force (Offence A) could ground liability for a collateral murder that the secondary parties did not intend to encourage or assist (Offence B).

\footnotetext{
${ }^{121}$ Admittedly, Collison's requirement of a resolution to resist opposition was adopted as an aspect of the offence of rioting, but that is irrelevant to the requirements of secondary liability. See Field v Metropolitan Police Receiver [1907] 2 K.B. 853; Ford v Receiver for Metropolitan Police District [1921] 2 K.B. 344.

${ }^{122}$ Smith, Complicity, 214.

${ }^{123}$ E.g. R. v Rubens (1909) 2 Cr. App. R. 163. See Smith, "Criminal Law" at p. 294; Smith, Complicity, 214215; Williams, Criminal Law, 398.

${ }^{124}$ (1913) 8 Cr. App. R. 198, 199.

${ }^{125}$ At 202-203.

${ }^{126}$ At 203. A similarly relaxed approach existed in conspiracy cases: Kerr (1921) 15 Cr. App. R. 165.

${ }^{127}$ Smith, "Criminal Law" at p. 294.
} 
Pridmore can be compared with $R . v$ Pearce, ${ }^{128}$ where the jury was told it would have to find an "arrangement" to use force if disturbed, and the existence of a common purpose "not merely to poach, but also to resist apprehension at all costs, even by violence if necessary", ${ }^{129}$ if it was to convict. The defendant had run away when his group was disturbed, and there was a concern that the trial judge had "misled" the jury to think that "the mere fact that [the parties] were out poaching together by night justified them in convicting both of any assault committed by one". ${ }^{130}$ But the earlier authorities are clear that secondary parties can withdraw from a criminal venture and thereby relieve themselves of further liability. ${ }^{131}$ Pearce had withdrawn. Furthermore, it is simply not clear what exactly would establish Pearce's liability, ${ }^{132}$ and the presumption of intention from natural and probable consequences still applied. ${ }^{133}$ Judges were thus not as careful to distinguish between intention/foresight and probability/foreseeability. Judicial comments must therefore be read cautiously.

Contemporary textbooks fail to resolve matters, even if they broadly support the need for a common purpose to resist opposition with force in (at least some) murder cases. For instance, the 1926 edition of Kenny's Outlines states that: ${ }^{134}$

An aider and abettor is only liable for such crimes committed by the principal in the first degree as were done in execution of their common purpose. Thus if burglars find themselves interrupted by the master of the house which they have broken into, and one of them shoots him, the other burglar [not be] liable for this murder, unless they had jointly resolved to resist interruption at any cost. [Emphasis added.]

No relevant cases are cited in support of this proposition, and there is no discussion of what this common resolution involved in terms of proof. Other secondary sources from the 1920s suggest that contemplation of the collateral offence was vital in such cases involving aiders and abettors, yet do not say that this was mere evidence that the secondary party had intentionally encouraged or assisted the collateral offence ${ }^{135}$ (which is what the Supreme Court/Privy Council suggested that it was). ${ }^{136}$

\footnotetext{
128 (1930) 21 Cr. App. R. 79.

129 At 81.

130 ibid.

${ }^{131}$ E.g., R. v Hyde (1672) 1 Hale P.C. 537.

132 See, similarly, R. v Short (1932) 23 Cr. App. R. 170.

${ }^{133}$ Though Woolmington v DPP [1935] A.C. 462 would soon eat away at it: Smith, Lawyers, 288-292. The presumption was already weakened in intoxication cases: see, e.g. R. v Meade [1909] 1 K.B. 895.

${ }^{134}$ C.S. Kenny, Outlines of Criminal Law, 12th ed. (Cambridge 1926), 87.

${ }^{135}$ E.g. H.W. Disney, The Criminal Law: A Sketch of its Principles and Practice, 2nd ed. (London 1926), 17.

${ }^{136}$ Questions of evidence and substantive law were, admittedly, not distinguished between neatly far into the twentieth century. See, e.g. Hyam v DPP [1975] A.C. 55, critiqued in R. v Maloney [1985] A.C. 905, 928-929.
} 
Despite these moves in the direction of "subjectivity", traces of the "objective", probability-based approach occurred relatively far into the twentieth century in cases involving principals in the second degree (aiders and abettors). In R. v Betts and Ridley, ${ }^{137}$ for example, the parties agreed to rob the victim (Offence A). The victim was killed during the robbery (Offence B). Ridley claimed that he agreed to a push, not further violence. It was held that Betts had merely altered the level of violence required to reach the agreed criminal objective. ${ }^{138}$ Ridley was thus "actually a party and privy to an act which was calculated in the judgment of ordinary people to cause death", ${ }^{139}$ and rightly convicted of murder. It is not clear whether this was a simple invocation of felony murder, or an application of a probabilitybased model of PAL. ${ }^{140}$ Either way, intentional assistance or encouragement of each of the principal's offences was not insisted upon. ${ }^{141}$ Other judicial statements from around the same time suggest an acceptance that acts beyond what the parties actually intended were at issue in common purpose cases. ${ }^{142}$ Even though it was (still) said that such acts were part of the common purpose, it was becoming clearer that this was intellectually dishonest.

By the mid-twentieth century, then, not all cases involving homicide rested on a settled common purpose to resist opposition with force, and those that did remained opaque regarding what this involved in terms of proof, and when the felony murder rule would straightforwardly apply. In the 1950 edition of Russell on Crime, edited by evangelical subjectivist Turner, ${ }^{143}$ it was still suggested: "that the true rule of law is, that where several persons engage in the pursuit of a common unlawful object, and one of them does an act which the others ought to have known was not improbable to happen in the course of pursuing such common unlawful object, all are guilty." "144 If the law had developed by the late nineteenth century to require an actual intention to encourage or assist Offence B (as the Supreme Court/Privy Council suggested), or even contemplation of Offence B, this was not noted over fifty years later by a leading criminal law commentator. ${ }^{145}$

\footnotetext{
${ }^{137}$ (1931) 22 Cr. App. R. 148.

138 At 155 .

${ }^{139}$ At $155-156$.

${ }^{140}$ Smith, Complicity, 216-217.

${ }^{141}$ Nor was "conditional intent", but $c f$. M. Giles, "Complicity: The Problems of Joint Enterprise" [1990] Crim. L.R. 383, 383 (n. 6) (hereafter Giles, “Joint Enterprise”).

${ }^{142}$ R. v Appleby (1943) 28 Cr. App. R. 1, 6.

${ }^{143}$ See Smith, Lawyers, 297-304.

${ }^{144}$ See n. 112.

${ }^{145}$ cf. L.F. Sturge (ed.), A Digest of the Criminal Law (Indictable Offences), 9th ed. (London 1950), art. 39.
} 
Even when "subjectivity" appeared to be insisted upon, an intention to assist or encourage the collateral offence was not. For instance, in Davies v DPP, Lord Simonds LC noted, obiter, that: ${ }^{146}$

I can see no reason why, if half a dozen boys fight another crowd, and one of them produces a knife and stabs one of the opponents to death, all the rest of his group should be treated as accomplices in the use of a knife and the infliction of mortal injury by that means, unless there is evidence that the rest intended or concerted or at least contemplated an attack with a knife by one of their number, as opposed to a common assault. If all that was designed or envisaged was in fact a common assault, and there was no evidence that [the defendant], a party to that common assault, knew that any of his companions had a knife, then [the defendant] was not an accomplice in the crime consisting in its felonious use. [Emphasis added.]

It is not clear whether contemplation was intended by Lord Simonds to be a sufficient condition for liability, ${ }^{147}$ but it was viewed as an alternative to intention. This casts doubt on the proposition that contemplation was mere evidence of intention, and nothing more, as the Supreme Court/Privy Council suggested in Jogee. ${ }^{148}$

Although one should hesitate before making grand claims based on vague, pre-1950 authorities and an obiter comment, it was at least possible that, by the mid 1950s, mere contemplation of the collateral crime was beginning to be required to bring an act within the parties' (constructed) common purpose. On the argument defended in this article, there had never been strong recognition of the need to prove that a secondary party intended to encourage or assist all of the principal's crimes, and so no climb-down to contemplation/foresight occurred.

Indeed, the view that the requisite "subjective" element was only just beginning to form by the 1950 s might explain why references to probability persevered. In $R$. v Grant, ${ }^{149}$ the defendants plotted to tie up and use light force against the porter at the hotel they were burgling. The principal used extreme violence on the porter, killing him. The parties' convictions for murder were upheld, but Grant did not agree to the level of violence used. It is not even clear if he contemplated it. The level of violence used was, however, viewed as a probable consequence of the plan to commit burglary and assault the porter. ${ }^{150}$ Of course, the felony murder rule still applied at that time, but it was abolished in $1957 .{ }^{151}$

\footnotetext{
146 [1954] A.C. 378, 401.

147 Jogee, at [40]; Wilson and Ormerod, "Joint Enterprise Reform”, 6.

${ }^{148}$ cf. Jogee, at [63].

149 (1954) 38 Cr. App. R. 107.

${ }^{150}$ cf. Smith, Complicity, 217.

${ }^{151}$ Homicide Act 1957, s. 1.
} 
In the 1958 edition of Russell on Crime, the statement about what the secondary party ought to have known was replaced by Turner with a reference to what "the evidence shows was within [the secondary party's] contemplation", though no cases are cited to explain this change in approach. ${ }^{152}$ The abolition of the felony murder rule would only explain a change of approach in murder cases: a bare felony would certainly no longer be enough (though it had not been treated as such, at least consistently, for some time). Yet it is instructive that Turner did not require that the secondary party intended to encourage or assist Offence B. Williams, by contrast, did note cases such as Collison in 1961, and viewed contrary authorities as unreliable. ${ }^{153} \mathrm{He}$ nevertheless suggested that a common intention to threaten violence "is equivalent to a common intent to use violence, for the one so easily leads to the other". ${ }^{154}$ This savours of recognition that collateral Offence B (violence) was a probable consequence of pursuing the plan to commit Offence A (the threat). It is not clear from Williams's discussion that contemplation of the use of violence was even required.

The cases continued to be largely inconsistent into the 1960 s. In $R$. v Spraggett, ${ }^{155}$ the Court of Appeal held that a "preconceived intention" to commit a crime of violence as well as the burglary was necessary before a conviction for the collateral offence of murder could follow. The court did not explain what this "preconceived intention" entailed in terms of proof. The presumption of intention from natural and probable consequences still applied at this stage, so it might have been sufficient that the collateral offence was a probable offshoot of the planned crime, or had at least been contemplated as such. Without this gloss, Spraggett is difficult to square with subsequent cases. In $R . v$ Betty, ${ }^{156}$ for example, the parties agreed to attack the victim, but did not intend to kill him. The trial judge had explained that the defendant could not be convicted of murder as a secondary party unless he contemplated the use of fatal or serious violence and the conviction was upheld. This suggests that contemplation was acceptable as the lowest form of fault required for secondary liability flowing from a common unlawful purpose. ${ }^{157}$ The defendant was convicted of manslaughter on the basis that he had not envisaged death or serious bodily harm resulting from the common purpose.

\footnotetext{
${ }^{152}$ J.W.C. Turner, Russell on Crime: A Treatise of Felonies and Misdemeanors, $11^{\text {th }}$ edn., vol. 1 (London 1958), 152. See Smith, Complicity, 213-214.

${ }^{153}$ cf. Williams, Criminal Law, 397 (n. 4).

154 ibid. 397-398.

${ }^{155}$ [1960] Crim. L.R. 840.

${ }^{156}$ (1963) 48 Cr. App. R. 6.

${ }^{157}$ cf. Jogee, at [30].
} 
There then followed two five-judge decisions from the Court of Appeal. In $R$. $v$ Smith, ${ }^{158}$ the court focussed on the secondary party's "foresight of consequences", noting that: $^{159}$

It must have been clearly within the contemplation of a man like Smith who ... had almost gone berserk himself to have left the public-house only to get bricks to tear up the joint, that if the bar tender did his duty to quell the disturbance and picked up the night stick, anyone whom he knew had a knife in his possession ... might use it on the barman ... By no stretch of imagination, in the opinion of this court, can that be said to be outside the scope of the concerted action in this case. [Emphasis added.]

All Smith did, if the argument presented above is accepted, is give support to the developing line of authority that mere probability of collateral offending was no longer enough for PAL, and that contemplation/foresight of the collateral crime was necessary. ${ }^{160}$ The trial judge's statements regarding intention are - on this view - to be treated with extreme care. ${ }^{161}$ Just because the trial judge said "intention" (still, at that time, presumed from "objective" probability) was required, does not mean that that was the minimum level of fault consistent with secondary liability. The decision was read at the time to suggest that contemplation of the collateral offence was necessary and sufficient. ${ }^{162}$ If a contemplation/foresight-based rot did set in during the twentieth century, then, this happened long before $1984{ }^{163}$

In the second five-judge decision, $R . v$ Anderson and Morris, ${ }^{164}$ the court approved the contention of Geoffrey Lane QC (later Lord Lane CJ) that the scope of the "joint enterprise" was crucial to establishing secondary liability, ${ }^{165}$ but said nothing about how it was to be established. ${ }^{166}$ The question is not answered in Anderson and Morris, ${ }^{167}$ which was mainly about unforeseeable changes to the common plan by the principal - which would relieve the putative secondary party of liability. But unforeseeable collateral offending would not even have fallen within the probability-based version of PAL that had existed (initially perhaps only in relation to counselling and procuring) from around the late seventeenth century, never mind the contemplation/foresight-based version that was developing (if falteringly) by the

\footnotetext{
158 [1963] 1 W.L.R. 1200.

159 At $1205-1206$.

${ }^{160}$ See R. v Rahman [2008] UKHL 45, [2009] 1 A.C. 129, at [13].

${ }^{161} c f$. Jogee, at [70]-[71].

162 See J.W.C. Turner, Russell on Crime: A Treatise on Crimes and Misdemeanors, 12th ed., vol. 1 (London 1964) 144; A. Hooper (ed.), Harris's Criminal Law, 21st ed. (London 1968), 78-79.

163 cf. Jogee, at [53].

164 [1966] 2 Q.B. 110.

165 At $118-119$.

166 Jogee, at [64].

${ }^{167} c f$. Wilson and Ormerod, "Joint Enterprise Reform", 8 (arguing that Anderson and Morris involved establishing "from an objective point of view, [what the secondary party] was signing up to").
} 
1960s. It is noteworthy that emphasis was placed in Anderson and Morris on whether the principal "acted in a way which no party to [the] common design could suspect". ${ }^{168}$ Again, it is not clear if suspicion would have been sufficient fault to bring the principal's offending within the responsibility of the secondary party, but it is not ruled out.

Following the demise of the presumption of intention and foresight from probable consequences (October 1967), ${ }^{169}$ and the abolition of the accessories before the fact/principals in the second degree distinction (January 1968), ${ }^{170}$ it might be expected that the law's approach would at last become consistent, but it did not. In R. v Lovesay, ${ }^{171}$ for example, liability required a "common design ... [to use] whatever force was necessary to achieve the robbers" object" ${ }^{172}$ but it seemed to be enough that the defendant "envisaged" that resistance would need to be overcome. ${ }^{173}$ That said, neither the decided cases, nor contemporary secondary literature, ${ }^{174}$ are crystal clear.

Indeed, some cases do appear to insist on an intention to encourage or assist each of the principal's offences. In R. $v$ Reid, Lawton LJ held that: ${ }^{175}$

\begin{abstract}
When two or more men go out together in joint possession of offensive weapons such as revolvers and knives and the circumstances are such as to justify an inference that the very least they intend to do with them is to use them to cause fear in another, there is ... always a likelihood that in the excitement and tensions of the occasion, one of them will use his weapon in some way which will cause death or serious injury. If such injury was not intended by the others, they must be acquitted of murder; but having started out on an enterprise which envisaged some degree of violence, albeit nothing more than causing fright, they will be guilty of manslaughter. [Emphasis added.]
\end{abstract}

Reid appears to be strong support for the Supreme Court/Privy Council's argument that, prior to 1984 , secondary parties had to intend to encourage or assist, and actually encourage or assist, each of the principal's offences. ${ }^{176}$ The court's decision in Reid was, however, viewed by J.C. Smith at the time as merely being "in accordance with the established law" described in the third edition of Smith and Hogan. ${ }^{177}$ There, it is said that if the secondary party expected the principal to use the knife with intent to cause grievous bodily harm, that was

\footnotetext{
${ }^{168}$ Anderson and Morris, at 120 (emphasis added).

${ }^{169}$ Criminal Justice Act 1967, s. 8.

${ }^{170}$ Criminal Law Act 1967, s. 1.

171 [1970] 1 Q.B. 352.

172 At 356

${ }^{173}$ ibid. See, further, R. v Dunbar [1988] Crim. L.R. 693. cf. Smith, Complicity, 219.

${ }^{174}$ See, e.g., J.C. Smith and B. Hogan, Criminal Law, 2nd ed. (London 1969), 88; J.C. Smith and B. Hogan, Criminal Law, 3rd ed. (London 1973), 102, 105.

175 (1976) 62 Cr. App. R. 109, 112.

${ }^{176}$ Though, again, in Jogee, at [72], an intention to encourage or assist murder and the mens rea of murder are elided.

${ }^{177}$ J.C. Smith [1976] Crim. L.R. 570, 571.
} 
murder, ${ }^{178}$ and the importance of foresight of the principal's crime was emphasised, but not connected (at least explicitly) with a requirement of intention. ${ }^{179}$ Once again, it is not clear that intentional assistance or encouragement of Offence B was, in the end, required.

Other authorities from around the same period support the view that contemplation or foresight of the principal's crime could be sufficient to secure secondary liability. In $R$. $v$ Penfold, ${ }^{180}$ Shaw LJ noted that the defendants could "hardly fail to contemplate" the necessity of violence, and they had implicitly agreed "to put themselves under the dictates of any arising necessity". ${ }^{181}$ It remained unclear whether this contemplation was a necessary and sufficient condition of liability. Although an alternative reading of the case is that the secondary parties had accepted that violence was indeed what they were planning (and "conditionally intended" it), contemplation of violence could well have been necessary and sufficient to affix liability. This dubiety is sufficient to cast doubt on the Supreme Court/Privy Council's historical account. Chan Wing-Siu could, on this contemplation-as-sufficient view, simply have confirmed what, by the late 1970s, was the best gloss put on the cases regarding common unlawful purpose. ${ }^{182}$ The law had narrowed after the sixteenth century's harsh approach, from concentrating on probable crimes committed in pursuit of the common purpose (through the seventeenth to nineteenth centuries - initially in counselling and procuring, and later generally) to contemplated crimes committed in pursuit of the common purpose. In another sense, the law's reach had broadened, in that possible (even if not probable) foreseen collateral crimes were seemingly included.

This question of possibility versus probability was addressed first in Australia. In $R$. $v$ Johns, ${ }^{183}$ Barwick CJ contended that the parties' common purpose included "all those contingencies which can be held to have been in the contemplation of the participants, or which in the circumstances ought necessarily to have been in such contemplation." ${ }^{~ 184}$ The defence conceded that contemplation of Offence B was enough, but objected to contemplation of a possibility being sufficient. ${ }^{185}$ It was concluded that it was. ${ }^{186}$ The Supreme Court/Privy

\footnotetext{
${ }^{178}$ Citing Betts and Ridley (1930) 22 Cr. App. R. 148.

${ }^{179}$ J.C. Smith and B. Hogan, Criminal Law, 3rd ed. (London 1973), 102-105. cf. DPP for Northern Ireland v Maxwell [1978] 1 W.L.R. 1350, at 1361 (“[S] must have contemplated that a violent attack of some kind was to be made ... When he obeyed the order he must therefore have intended to assist in carrying out such an attack"). 180 (1980) 71 Cr. App. R. 4.

181 At 8 .

182 cf. D.J. Ibbetson, “The Mental Element in Complicity” (1982) 2 O.J.L.S. 287, 287.

183 (1980) 143 C.L.R. 108.

${ }^{184}$ At 113.

185 At 125 .

${ }^{186}$ At 118-119, citing C. Howard, Criminal Law, 3rd ed. (Sydney 1977), 276. cf. R. v Jubb and Rigby [1984] Crim. L.R. 616.
} 
Council thought that Johns supported its approach, and was consistent with its reading of Collison. ${ }^{187}$ Admittedly the judges' statements in Johns are inconsistent, ${ }^{188}$ but that makes claims about it reflecting an "orthodox" 189 and "long-standing" position, ${ }^{190}$ or having a clear ratio, ${ }^{191}$ problematic.

It has been argued that the trend in the twentieth century cases was towards identifying a "subjective" element beyond the intention to encourage or assist Offence A, but this was not necessarily an intention to encourage or assist Offence B. The Supreme Court/Privy Council bases its contrary thesis on eight twentieth-century cases (Spraggett, Betty, Smith, Anderson and Morris, Reid and Johns). ${ }^{192}$ Many of these authorities are at best inconclusive, and at worst inconsistent with the intention-based account. Requiring simple contemplation of Offence B is, it is submitted, consistent with a far greater number of authorities, and represents a proper "subjective" equivalent of the "objective" probability focus that dominated earlier discussions of accessorial liability. That, it is submitted, is the best historical account of the law before 1984. Indeed, in the 1983 edition of his Textbook, Williams suggested that "It is now clear that if D1 and D2 set out to rob, and D2 knows that D1 may be carrying a gun and may use it, D2 will be an accomplice in an offence committed by D1 with the gun, if it is in the course of the robbery or of escaping afterwards." ${ }^{193}$ The pivotal question can now, thus, be answered: did the Privy Council take a bold new step in Chan Wing-Siu?

\section{WAS CHAN WING-SIU NEW?}

In light of the discussion above, the thesis that the Privy Council's decision in Chan Wing-Siu bucked a clear trend in endorsing intention as the fault element in all instances of secondary liability, and introduced a "new principle" 194 that changed "the common law in a way which made it more severe... widening the scope of secondary liability by the introduction of new

\footnotetext{
${ }^{187}$ Jogee, at [44]. See, too, at [67].

${ }^{188}$ See the discussion in ibid. at [43].

189 ibid. at [44].

190 ibid. at [87].

191 ibid. at [67].

192 The Australian case of R.v Miller (1980) 1 A. Crim. R. 165 was also cited, but is irrelevant: the parties' common purpose was lawful.

${ }^{193}$ G. Williams, Textbook of Criminal Law, 2nd ed. (London 1983), 352 (cf. the comments about express agreements and untrustworthy principals at 355). The difference between knowing $x$ may happen and foreseeing $x$ might happen is unaddressed.

${ }^{194}$ Jogee, at [62].
} 
doctrine", ${ }^{195}$ is highly suspect. Although it was claimed in Jogee that Chan Wing-Siu was "based on an incomplete, and in some respects erroneous, reading of the previous case law", ${ }^{196}$ the Supreme Court/Privy Council cannot escape a similar charge. The court cited selectively, giving the most sympathetic view of history that it could. On the alternative history argued for in this article, which it is submitted explains more of the decided cases, Chan Wing-Siu (despite the Privy Council citing few cases) simply confirmed what was already becoming clearer in the case law: there was a "wider principle" (i.e. PAL) beyond standard aiding and abetting, "whereby a secondary party is criminally liable for acts by the primary offender of a type which the former foresees but does not necessarily intend". 197 Indeed, the appellants in Chan Wing-Siu do not seem to have argued otherwise, basing their case on the requirement of foresight of a probability of collateral offending, rather than suggesting intention was the relevant standard (although they maintained the intellectual muddle of claiming there to be "tacit agreement" regarding Crime B where in fact there was none). ${ }^{198}$

The intellectual honesty of Chan Wing-Siu was that it was no longer pretended that the collateral offence was within the common purpose, even conditionally; at last, the law admitted that it was not, yet remained the secondary party's responsibility. Unfortunately, some intellectual dishonesty remained due to the mentions of "authorisation", "consensus" and "tacit" agreement, where in fact there was bare foresight of the collateral offending. ${ }^{199}$ But these were unnecessary embellishments. As the Privy Council explained: "The criminal culpability lies in participating in the venture with [foresight of Crime B]" ${ }^{200}$ The House of Lords later clarified this point in Powell and English, ${ }^{201}$ where it was confirmed (albeit with some reservations $)^{202}$ that foresight of the collateral offending was necessary and sufficient in PAL cases. Short of being aberrations, then, it is submitted that Chan Wing-Siu and Powell and English were helpful clarifications of the law.

Indeed, had the decision in Chan Wing-Siu been as revolutionary and flawed as the Supreme Court/Privy Council suggested, one might have expected this to be noticed. Yet, in 1984, J.C. Smith described the Privy Council's decision as "a valuable restatement and

\footnotetext{
195 ibid. at [74].

${ }^{196}$ ibid. at [79].

${ }^{197}$ Chan Wing-Siu, 175.

198 ibid. at $170-171$.

199 Jogee, at [65]-[66]. cf. B. Krebs, “Mens Rea in Joint Enterprise: A Role for Endorsement?” (2015) 74 C.L.J. 480, 493-495 (hereafter Krebs, "Endorsement").

${ }^{200}$ Chan Wing-Siu, 175.

${ }^{201}$ [1999] 1 A.C. 1 (seen by Smith as a "valuable clarification": [1998] Crim. L.R. 48, 49).

202 At $10-11$.
} 
clarification of ... the law". ${ }^{203}$ This was not simply a case of the significance of the decision being missed in its immediate aftermath. In 1997, Smith stated that: "It would be quite wrong to suppose that parasitic accessorial liability ... is a recent development in the law, an innovation by the Privy Council in Chan Wing-Siu." ${ }^{204}$ Similarly, Spencer, writing in 1985, thought that the Privy Council's decision was consistent with the contemporary English approach, ${ }^{205}$ not a new development. ${ }^{206}$ The 1985 edition of Archbold mentions Chan WingSiu only once, without adverse comment. ${ }^{207}$ Although the case was not initially applied universally, ${ }^{208}$ the Court of Appeal endorsed it fairly promptly. ${ }^{209}$

Once the dust had settled, some authors began to question the efficacy of the decision in Chan Wing-Siu. ${ }^{210}$ In 1987, Dennis presaged the Supreme Court/Privy Council's decision in Jogee by reading Chan Wing-Siu to be a case about so-called "conditional intention"; otherwise, it was a "dubious" decision, due to the tightening in the mens rea of murder (for principals) after $1984 .{ }^{211}$ Yet, in his magisterial 1991 work on complicity, K.J.M. Smith thought that Chan Wing-Siu had merely gone "some way to (finally) settling the [fault element of secondary liability for collateral crimes], although distinct traces of confusion are still discernible in the use of consensus terminology". ${ }^{212}$ As noted above, that confusion was removed in Powell and English.

The claim that Chan Wing-Siu was a "wrong turn", and departing from it was in large part a matter of precedent (and therefore constitutionally straightforward), is thus unconvincing. The more compelling reading of Jogee is that the Supreme Court/Privy Council engaged in substantive law reform. This could have been made explicit, and the decision sold as a continuation of the historical narrowing of PAL. Just as the law had moved from a focus on: (i) furthering the common purpose, to (ii) probable collateral offending, to (iii) contemplated/foreseen collateral offending, it was now moving to focus on (iv)

\footnotetext{
${ }^{203}$ [1984] Crim. L.R. 550. See, similarly, D. Cowley, "Complicity: Liability for Unintended Consequences" (1985) 49 J. Crim. L. 38, 38.

${ }^{204}$ Smith, "Accessories", 456. See Gnango [2010] EWCA Crim 1691, [2011] 1 W.L.R. 1414, at [67].

${ }^{205}$ J.R. Spencer, "On Contemplating the Range of Contemplation" [1985] C.L.J. 8, 9.

${ }^{206}$ J.R. Spencer, "Jogee - the 'Parasite' Excised" [2016] 3 Arch. Rev. 4, 4.

${ }^{207}$ M. Stephen, P.J. Richardson and J.H. Buzzard, Archbold's Pleading, Evidence and Practice in Criminal Cases, $42^{\text {nd }}$ edn. (London 1985) para. 20.16. cf. para. 29.3: "The cases on [joint enterprise] are not easy to reconcile".

${ }^{208}$ E.g. R. v Smith [1988] Crim. L.R. 616.

${ }^{209}$ Ward (1987) 85 Cr. App. R. 71; R. v Slack [1989] Q.B. 775; R. v Hyde [1991] 1 Q.B. 134. See, further, G.J. Virgo, "Accessory to Murder - Foresight or Intention?" (1990) 49 C.L.J. 6.

${ }^{210}$ A.L.T. Choo, "Joint Unlawful Enterprises and Murder" (1992) 55 M.L.R 870, 871.

${ }^{211}$ I. Dennis, "The Mental Element for Accessories" in P. Smith (ed.), Criminal Law: Essays in Honour of J.C. Smith (London 1987) 40 at pp. 43-44, 56-58, 61. See, also, Wilson and Ormerod, "Joint Enterprise Reform".

${ }^{212}$ Smith, Complicity, 220. See, similarly, Assisting and Encouraging Crime (Law Com. C.P. No. 131, 1993) para. 2.113; Giles, "Joint Enterprise", 385-386.
} 
intentional encouragement/assistance of the collateral crime, thus rendering PAL conceptually identical to ordinary aiding and abetting (and redundant). Many would have viewed such a judicial change as desirable, regarding PAL - a judicial development - as the genesis of much injustice. ${ }^{213}$ Being explicit about the change would, however, have meant engaging more directly with the proper process of revisiting previous decisions, ${ }^{214}$ and raised more clearly constitutional concerns about judicial activism. Although the Supreme Court/Privy Council is no doubt right that corrections of clear common law "errors" are largely unproblematic constitutionally, ${ }^{215}$ there are clearer concerns raised by more substantive reform of even the common law $^{216}$ (as the prosecution maintained in Jogee). ${ }^{217}$ The reasons the change in Jogee is problematic, once the alleged precedential "error" has been exposed as a smokescreen, are as follows: (i) the law as stated (defensibly, as shown above) in Chan Wing-Siu had been relatively settled for over 30 years; (ii) requiring intentional encouragement or assistance for all secondary liability was not a reform the Law Commission had proposed when it had considered accessorial liability; ${ }^{218}$ and (iii) Parliament had not apparently contemplated reforming the law, despite recent encouragement to do so. ${ }^{219}$ Once that shield of precedent and history has been shattered, the question is whether the other reasons provided by the Supreme Court/Privy Council in Jogee $e^{220}$ justified such dramatic law reform being undertaken by the courts, not the legislature. It is unfortunate that this question was so easily avoided in Jogee, but this paper opens up the possibility for it to be addressed more straightforwardly in the future. Jogee should be seen for what it is: significant judicial law reform, not common law housekeeping.

\footnotetext{
${ }^{213}$ See, further, Wilson and Ormerod, "Joint Enterprise Reform", at 26, citing the departures from Hyam v DPP [1975] A.C. 55 (on murder) and R. v Caldwell [1982] A.C. 341 (on recklessness) as examples of previous judicially-created injustices being resolved by the courts. Yet, Hyam was a decision on far thinner doctrinal ice than Chan Wing-Siu and stood for a far shorter time, and Caldwell straightforwardly misinterpreted Parliament's intention.

${ }^{214}$ See Supreme Court Practice Direction 3.1.3; Practice Statement (Judicial Precedent) [1966] 1 W.L.R. 1234.

215 Jogee, at [85].

${ }^{216}$ See $C v D P P$ [1996] 1 A.C. 1; F. Stark, "R. v Howe (1987)" in P. Handler, H. Mares and I. Williams (eds.), Landmark Cases in Criminal Law (Oxford, forthcoming).

${ }^{217}$ Jogee, at [3].

${ }^{218}$ See, most recently, Participating in Crime (Law Com. No. 305, 2007) paras. 3.123-3.162.

${ }^{219}$ The government has not responded positively to prompts to reform the law: see Krebs, "Endorsement", 482.

${ }^{220}$ At [81]-[86].
} 